\title{
REVIEW
}

\section{Capturing Alzheimer's disease genomes with induced pluripotent stem cells: prospects and challenges}

\author{
Mason A Israel* and Lawrence SB Goldstein*
}

\begin{abstract}
A crucial limitation to our understanding of Alzheimer's disease (AD) is the inability to test hypotheses on live, patient-specific neurons. Patient autopsies are limited in supply and only reveal endpoints of disease. Rodent models harboring familial AD mutations lack important pathologies, and animal models have not been useful in modeling the sporadic form of $A D$ because of complex genetics. The recent development of induced pluripotent stem cells (iPSCs) provides a method to create live, patient-specific models of disease and to investigate disease phenotypes in vitro. In this review, we discuss the genetics of AD patients and the potential for iPSCs to capture the genomes of these individuals and generate relevant cell types. Specifically, we examine recent insights into the genetic fidelity of iPSCs, advances in the area of neuronal differentiation, and the ability of iPSCs to model neurodegenerative diseases.
\end{abstract}

\section{Introduction: from AD patient genome to 'disease in a dish'}

Alzheimer's disease (AD) is a common, fatal neurodegenerative disease that currently afflicts more than 35 million people worldwide [1]. With the increasing longevity and aging of many populations around the world, the devastation caused by $\mathrm{AD}$ to patients, their families, societies and economies is growing. Currently, there is no approved treatment with a proven diseasemodifying effect [2].

Mechanistic studies of AD generally rely on autopsy samples, which are limited in supply and contain the disease aftermath, or on animal models, which do not

*Correspondence: misrael@ucsd.edu; Igoldstein@ucsd.edu Department of Cellular and Molecular Medicine, University of California San Diego, La Jolla, CA 92093, USA fully recapitulate $\mathrm{AD}$ pathogenesis. Consequently, it has been very difficult to elucidate the initiating events of AD. Furthermore, recent clinical trials for AD have been largely disappointing. A proper understanding of the initiating events of $\mathrm{AD}$ and the existence of live disease models that accurately recapitulate the pathogenesis would lead to a much better informed therapeutic development effort.

Within the past few years, genome-wide association studies (GWAS) of AD have uncovered new susceptibility genes for the sporadic form of AD (sAD), and many of these genes appear to be part of similar biochemical pathways. Nevertheless, creating systems that can validate and study these genes has been a major challenge.

Induced pluripotent stem cell (iPSC) technology has the potential to capture the genomes of AD patients and to generate live cellular models of both the familial $\mathrm{AD}$ (fAD) and SAD. These models might allow us to identify the earliest events of $\mathrm{AD}$, to investigate aspects of $\mathrm{AD}$ pathogenesis that are not recapitulated in animal models, and to validate and build upon findings from GWAS.

In this review, we begin by summarizing our current understanding of the genetics and genomics of $\mathrm{AD}$, and continue by discussing recent studies of iPSCs that are relevant to the study of AD. As AD is a complex neurodegenerative disease, we focus on studies of the genomic fidelity of iPSCs, on research on the differentiation of iPSCs into neural cells, and on the modeling of neurodegenerative diseases in vitro.

\section{Alzheimer's disease: clinical features and pathology} At the cognitive level, AD begins with deficits in the ability to form new memories. These deficits are similar to those that occur during the normal aging process but in $\mathrm{AD}$ they subsequently progresses to global cognitive decline. For most patients, disease onset occurs after the age of 65 years (late-onset $\mathrm{AD}$ ), but early-onset $\mathrm{AD}$, in which dementia can begin as early as the third decade, also exists. The pathological course of the disease, as measured in post-mortem samples, appears to parallel the cognitive decline closely: the hallmark pathologies of 
AD initially appear in regions of the brain that are associated with the formation of new memories, such as the hippocampus and entorhinal cortex, and culminate in near global neurodegeneration.

Two hallmark pathologies are used to diagnose $\mathrm{AD}$ definitively and both are thought to be crucial in disease pathogenesis. The first, amyloid plaques, are cerebral extracellular deposits primarily composed of amyloid $\beta$ (A $\beta$ ) peptides $[3,4]$. The second, neurofibrillary tangles, are filamentous accumulations of hyperphosphorylated tau protein located in the somatodendritic compartment of neurons [1].

Because the plaques and tangles from a given $\mathrm{AD}$ patient are not available for study until autopsy, often only after the endpoint of disease, it has been very difficult to determine how plaques and tangles contribute to disease progression. Live models of AD that accurately recapitulate the pathogenesis are therefore of great potential value.

In addition to the two hallmarks, many other pathologies have been observed at autopsy. Some, such as accumulations of endocytic and axonal vesicles, have been seen very early in disease pathogenesis [5,6]. Other pathologies that are detected more frequently in $\mathrm{AD}$ autopsies than in control samples include a reduction in synapse number, a reduction in neurotrophin levels, damage to mitochondria, aberrant cell cycle re-entry, calcium signaling dysregulation, and the activation of astrocytes and microglia [1]. Another class of $\mathrm{AD}$ pathologies, including vascular disease, cholesterol dysregulation, and reduction of insulin-pathway components, are only observed in subsets of AD patients [1]. The relative importance of both the hallmarks and all of these pathologies to disease initiation and propagation, though of extreme interest, is obscured by the limitations of animal models and evidence from autopsies. An abundant source of live, patient-specific neural cells could allow researchers to probe the contributions of these pathologies to overall pathogenesis.

\section{Genetics and genomics of Alzheimer's disease Familial AD}

Major breakthroughs in the current understanding of $\mathrm{AD}$ came in the 1990s when research groups identified three genes that were mutated in rare, dominantly inherited forms of early-onset AD (called fAD) [7-10]. These genes encode the amyloid precursor protein (APP), presenilin 1 and presenilin 2. Interestingly, all three proteins play important roles in the biochemical pathway that generates amyloid plaques. $A \beta$ peptides are aggregation-prone protein fragments that are cleaved from APP, a process that involves the proteolytic enzymes $\beta$-secretase and $\gamma$ secretase. The presenilins constitute a necessary subunit of $\gamma$-secretase [11].
This genetic evidence is the foundation of the predominant hypothesis of $\mathrm{AD}$ pathogenesis: the amyloid cascade hypothesis. The main tenet of this hypothesis is that pathologically elevated levels of $A \beta$ or an increase in the ratio of $A \beta^{1-42}$ to $A \beta^{1-40}$ is necessary and sufficient to trigger disease [12]. There is, however, a growing body of evidence that aberrant levels of other components of the APP processing pathway, such as the APP $\beta$ carboxyterminal fragments or cleaved amino-terminal fragments, can drive pathogenesis (reviewed in [13]).

Another major weakness of the amyloid cascade hypothesis is that animal models that harbor fAD mutations, although they have contributed invaluably to our current understanding of $\mathrm{AD}$, fail to recapitulate $\mathrm{AD}$ pathogenesis fully. Mouse models that overexpress fAD-mutant forms of APP and/or presenilin 1 develop plaques but fail to develop tangles or significant neurodegeneration (reviewed in [14]). Mouse models that develop both plaques and tangles exist but are additionally transgenic for human tau: they contain the P301L mutation found in another form of dementia known as frontotemporal dementia with parkinsonism linked to chromosome 17 (FTD-17) [15]. Important species-specific differences in genome and protein composition are probably major causes of the limitations of mouse models. Indeed, Geula et al. [16] observed differences in response to injected amyloid preparations between rodents and primates and between two different primate species. The generation of accurate human models of $\mathrm{AD}$ has the potential to provide a powerful way to study or avoid differences between species.

\section{Sporadic AD}

Another major gap in our current understanding of $\mathrm{AD}$ is the issue of sAD. The vast majority (>95\%) of AD appears to be SAD [17]. Although SAD and $\mathrm{AAD}$ have identical end-stage neuropathologies, SAD is generally late-onset and its underlying genetics are surprisingly different from those of fAD. Sporadic AD is thought to be caused by a combination of multiple gene variants and environmental factors. In a large study of twins, the genetic contribution to SAD was estimated to be $58-79 \%$ [18]. Table 1 provides details of the genes that, to date, have been found to associate most strongly with SAD and fAD.

Recently, several GWAS have identified multiple gene variants that are associated with AD (reviewed in [19]). Interestingly, none of the top GWAS hits have been in $A P P$ or the presenilin genes. Many of the identified risk variants have odds ratios $<1.2$ and their associations with $\mathrm{AD}$ have not been replicated in independent studies. Factors that contribute to this lack of independent replication probably include the distributions of expressivity of the risk variants and differences in the study populations: it has been observed that the contribution of at 
Table 1. Genes most strongly associated with fAD and sAD*

\begin{tabular}{|c|c|c|c|c|c|}
\hline Gene & AD type & Product & Function or pathway & ID method & Reference(s) \\
\hline$A P P$ & Familial & Amyloid precursor protein & $\begin{array}{l}\text { Cell surface receptor, vesicle trafficking, } \\
\text { cell signaling }\end{array}$ & Pedigree & {$[79,80]$} \\
\hline PSEN1 & Familial & Presenilin 1 & Proteolytic subunit of $\gamma$-secretase & Pedigree & [10] \\
\hline PSEN2 & Familial & Presenilin 2 & Proteolytic subunit of $\gamma$-secretase & Pedigree & {$[8,9]$} \\
\hline APOE & Sporadic & Apolipoprotein E & $\begin{array}{l}\text { Apoprotein, catabolism of triglyceride-rich } \\
\text { lipoprotein constituents, endocytosis }\end{array}$ & Candidate, GWAS & [81-83] \\
\hline CLU & Sporadic & Clusterin (Apolipoprotein J) & Secreted chaperone & Candidate, GWAS & {$[21,22,84]$} \\
\hline PICALM & Sporadic & $\begin{array}{l}\text { Phosphatidylinositol-binding } \\
\text { clathrin assembly protein }\end{array}$ & Clathrin assembly, endocytosis & GWAS & [21] \\
\hline EXOC3L2 & Sporadic & Exocyst complex component 3-like 2 & Unclear & GWAS & [23] \\
\hline$B I N 1$ & Sporadic & $\begin{array}{l}\text { Bridging integrator } 1 \\
\text { (amphiphysin II) }\end{array}$ & $\begin{array}{l}\text { Nucleocytoplasmic adaptor protein, possible } \\
\text { role in synaptic vesicle endocytosis }\end{array}$ & GWAS & [23] \\
\hline$C R 1$ & Sporadic & Complement receptor 1 & Complement cascade regulation & GWAS & [22] \\
\hline SORL1 & Sporadic & Sortilin-related receptor & $\begin{array}{l}\text { Low density lipoprotein receptor family } \\
\text { member, possible role in endocytosis and } \\
\text { sorting }\end{array}$ & Candidate & {$[85]$} \\
\hline GWA_14q32.13 & Sporadic & Unknown & Unclear & GWAS & [86] \\
\hline TNK1 & Sporadic & Tyrosine kinase, non-receptor 1 & Nonreceptor tyrosine kinase & GWAS & [86] \\
\hline IL8 & Sporadic & Interleukin 9 & $\begin{array}{l}\text { CXC chemokine family member, mediation } \\
\text { of inflammatory response }\end{array}$ & Candidate & {$[87]$} \\
\hline
\end{tabular}

*Top 10 results from AlzGene database [78], accessed March, 2011.

least some susceptibility genes to AD depends on the genetic background of the patients [20].

However, two recent large GWASs by Harold et al. [21] and Lambert et al. [22] have identified a handful of susceptibility genes with genome-wide significance, each study confirming the main findings of the other. Both studies genotyped approximately 15,000 patients and controls for approximately 600,000 single nucleotide polymorphisms (SNPs). The individuals studied by Lambert et al. [22] were of French Caucasian descent, whereas those studied by Harold et al. [21] came from the United States and several countries in western Europe. Consistent with other AD GWAS, the association between $\mathrm{AD}$ and the apolipoprotein $\mathrm{E}$ gene APOE4 dominated the results of both studies. The clusterin gene $C L U$ (also known as Apolipoprotein J (APOJ)) also reached genome-wide significance in both studies. Two other genes, the phosphatidylinositol-binding clathrin assembly protein gene PICALM and Complement receptor type 1 (CR1), reached genome-wide significance in one study and sub-genome-wide significance in the other. Not only did each study confirm, at least to some degree, the findings of the other, but these four susceptibility genes have been observed in more recent GWASs [23].

\section{Linking GWAS findings to AD pathogenesis}

Both APOE and CLU are lipoproteins that are found in the brain, with APOE being the predominant brain lipoprotein (reviewed in [24-26]). Both gene products can act as secreted chaperones that can bind many ligands, including $A \beta$. Although not fully elucidated, it is widely thought that the risk variants of these lipoproteins promote AD pathogenesis by affecting the extracellular concentration, localization and/or fibrillization of $\mathrm{A} \beta$.

Risk variants of CR1 and PICALM have also been proposed to contribute to AD pathogenesis by affecting extracellular A $\beta$ concentration and/or localization [26,27]. CR1 plays a role in regulating the complement cascade and has been observed to mediate $A \beta$ clearance through $\mathrm{C} 3 \mathrm{~b}$ binding [28]. The phosphatidylinositol-binding clathrin assembly protein encoded by PICALM is involved in clathrin-mediated endocytosis. Thus, PICALM risk variants may alter endocytosis-mediated clearance of $\mathrm{A} \beta$, although PICALM has also been found to play a role in synapse function [29]. Alternatively, PICALM risk variants might cause or exacerbate the endosomal pathologies observed in AD [30].

The roles of many of the other susceptibility genes identified by GWAS in AD pathogenesis are similarly unclear, but a large percentage of these genes are known to have roles in lipid metabolism, cardiovascular disease and inflammation. There is evidence of direct or indirect relationships between $\mathrm{A} \beta$ and many of the gene products. Nevertheless, it has been difficult to link the GWAS findings with mechanisms of AD precisely, in part because current GWAS technology does not identify the actual genetic changes that are responsible for altered risk (reviewed in $[26,27]$ ). It will be important to determine if 


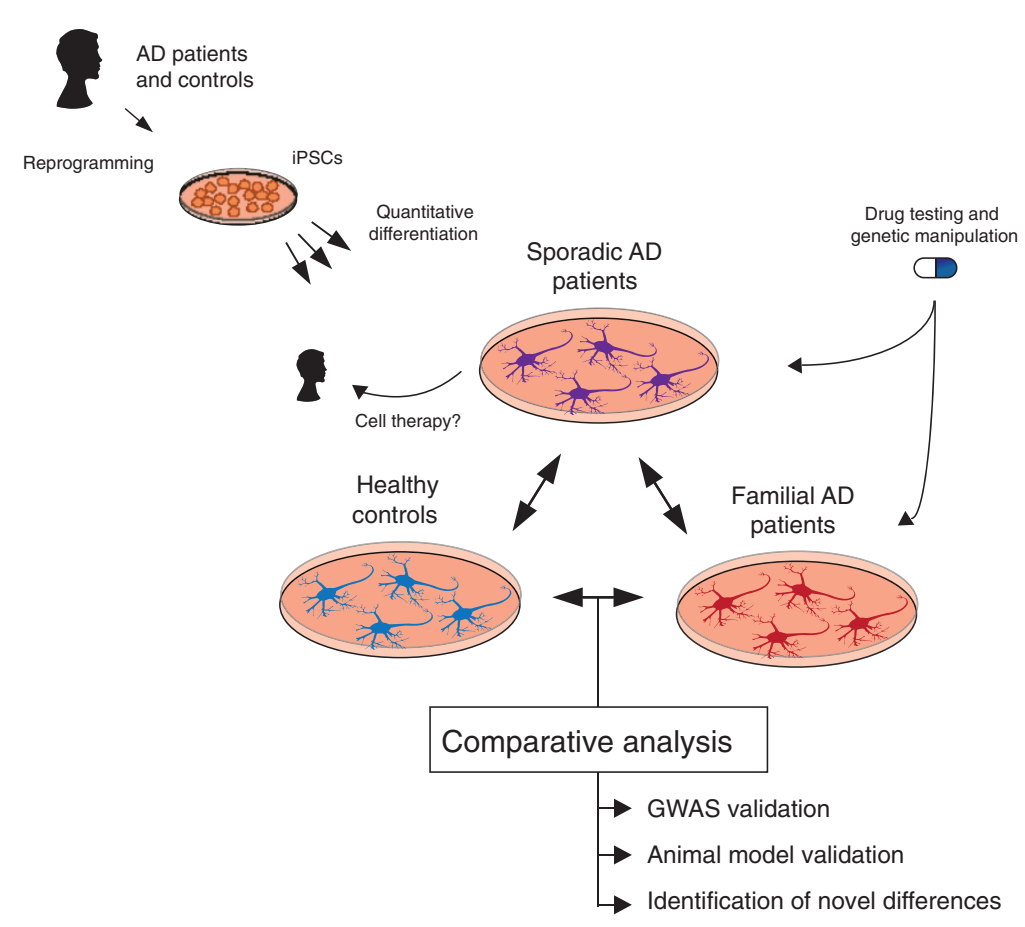

Figure 1. A general approach for the use of iPSCs to model AD. Samples from sporadic AD patients, familial AD patients and 'healthy' controls are reprogrammed into iPSC lines. iPSCs are then differentiated into cell types of interest, such as neurons, using quantitative methods that compare differentiation efficiency between lines and patients. By comparing iPSC-derived neurons and/or glia between individuals, it may be possible to validate findings from GWAS and animal models studies and to identify novel initiating events of AD. For example, do iPSC-derived neurons from fAD patients have aberrant A $\beta$ secretion? Do iPSC-derived neurons from SAD patients resemble fAD samples?

a given gene plays a role in initiating $\mathrm{AD}$ or if it modifies the age of onset of a disease progression that is already set in motion.

Collectively, AD GWASs provide strong evidence that $\mathrm{AD}$ has complex genetic contributions, and help to explain why it has not been possible to model SAD in mice. Given the difficulty in modeling fAD and SAD in mice, the validation of the $\mathrm{AD}$ susceptibility genes identified by GWAS and the determination of their biological relevance remain as key issues. Creating cellular models of patients in whom risk variants have high expressivity could provide a novel approach to this end.

\section{iPSCs as tools to make live, patient-specific neuronal cultures \\ iPSC technology}

The recent development of iPSC technology provides a method to create live, patient-specific models of disease and to investigate disease phenotypes in vitro [31,32]. iPSCs are most commonly made by taking a small skin biopsy from a patient, expanding the biopsy into primary fibroblasts, and transducing the cells with retroviruses that encode the transcription factors OCT4, SOX2, KLF4 and cMYC. Amazingly, the resultant reprogrammed cell lines, if of sufficient quality, are patient-specific stem cell lines that appear to divide indefinitely and can theoretically differentiate into any cell type in the human body. Thus, these lines provide a novel method to make abundant quantities of live, patient-specific neurons and glia. iPSC technology has been touted as a method to create both 'diseases in a dish' and novel platforms for therapeutic development. Nevertheless, it has yet to be demonstrated that iPSCs can be used to model AD or indeed any complex genetic disease. A potential approach for the use of iPSCs in modeling AD is illustrated in Figure 1.

Recently, new methods to generate iPSCs using excisable, non-integrating and DNA-free vectors have been published (reviewed in [33]). Transgene-free iPSCs might be beneficial for certain applications, such as transplantation, but many of these methods have yet to be used successfully for disease modeling. Additionally, Pang et al. [34] recently reported a method for the direct conversion of human fibroblasts into neurons. Cultures of perinatal fibroblasts that were transduced with the transcription factors Brn2, Ascl1, Myt1l and NeuroD1 rapidly converted into cultures containing neurons. These neurons, which appeared to be primarily glutamatergic, could be matured to display spontaneous electrical activity. In its current form, this method has significant 
limitations for the study of $\mathrm{AD}$, including the facts that patient fibroblasts are much more exhaustible than iPSCs and that non-neuronal cells play important roles in the pathogenesis. Nevertheless, it provides a provocative clue to suggest that by modulating core transcriptional networks, we may be able to direct patient samples to precise cell types of interest, including the neuronal subtypes that are lost early in the pathogenesis of AD (such as basal forebrain cholinergic neurons).

\section{Genomic fidelity and genetic manipulation of iPSCs}

iPSCs need to maintain a high degree of genetic fidelity if they are to model a complex genetic disease such as AD. This issue was addressed recently by comparing at high resolution the genomes of iPSCs relative to those of the patients they represent [35-38]. Gore et al. [37] investigated genetic fidelity by sequencing the exomes (approximately [37] 84\% coverage) of iPSC lines and their parental fibroblasts. In addition, these researchers obtained and sequenced iPSC lines made from two individuals whose genomes have been published. They reported the results for 22 iPSC lines, made by several different laboratories using multiple reprogramming methods. Coding point mutations were found in all 22 lines, with an average of five protein-coding mutations per line. Some of these mutations were present in the parental fibroblast cultures at low frequencies, whereas other mutations appeared to result from the reprogramming and clonal expansion processes. In two similar studies, gene copy number variants (CNVs) were analyzed in large numbers of iPSC lines using high-resolution SNP arrays. Both studies found that CNVs were very common in iPSCs [36,38]. All of these recent studies of genetic fidelity found genetic aberrations in iPSC lines, but they existed at relatively low frequencies, and the collection of aberrations in any two lines rarely appeared to overlap. This suggests that iPSCs do indeed have a high degree of genetic fidelity to their respective donors. The presence of a small number of mutations might complicate disease modeling studies, but it is likely that these can be remedied if each donor individual is represented by multiple, independently derived iPSC lines. These mutations become an issue of much greater concern in transplantation studies, however, especially as some of the genetic aberrations that were observed in iPSCs affected oncogenic loci.

Another important feature of iPSCs is their amenability to genetic manipulation. A wide range of gene-targeting techniques, including homologous recombination and the use of zinc-finger nucleases, have been successfully applied to iPSCs [39-41]. Adding or removing the AD mutations, risk factors and/or protective factors found in GWAS might provide a better understanding of the role that genetic background plays in $\mathrm{AD}$, and might allow determination of the penetrance of risk factors. With this approach, it might also be possible to assess the contribution of low-risk variants to disease phenotypes and drug responses.

\section{Directed differentiation of iPSCs}

The reliable directed differentiation of iPSCs into cell types that are affected by disease remains a major challenge in the stem cell field. In the case of $\mathrm{AD}$, affected cell types include neurons, astrocytes and microglia [1]. It is commonly thought that glutamatergic and basal forebrain cholinergic neurons are among the neuronal subtypes lost in the early stages of $A D$, whereas $\gamma$-aminobutyric acid transmitting (GABAergic) and additional subtypes are lost by the advanced stages [42]. Although iPSCs readily differentiate into heterogeneous cultures that contain $\mathrm{MAP}^{+}$(microtubule associated protein 2 positive) neurons and $\mathrm{GFAP}^{+}$(glial fibrillary acidic protein positive) astrocytes, most protocols yield cultures that contain a high percentage of uncharacterized cell types and might not consistently yield the same subtypes of neurons.

Findings from developmental neuroscience have recently been applied to provide methods to differentiate pluripotent stem cells into electrophysiologically active neurons that resemble glutamatergic and basal forebrain cholinergic subtypes [43-45]. Bissonnette et al. [44] reported a method for differentiating a human embryonic stem cell (hESC) line into neurons that simultaneously expressed the cholinergic marker ChAT (choline acetyltransferase) and forebrain-associated markers, such as p75NTR (neurotrophin receptor). Additionally, some neurons from these cultures, when co-cultured with mouse ex vivo entorhinal-hippocampal cortical slices, were capable of acetylcholine release at nicotinic synapses formed with ex vivo neurons. Marchetto et al. [45], in their study of Rett syndrome using iPSCs, reported the differentiation of iPSCs in vitro into neuronal cultures that contained glutamatergic synapses and were capable of generating spontaneous synaptic activity [45]. These two studies exemplify how pluripotent stem cells can differentiate into functional neurons of subtypes relevant for the study of AD. Furthermore, the spontaneous synaptic activity observed in differentiated neurons hints that iPSC technology can be used to study not only human neurons but also patient-specific neural networks. However, future progress using these methods will rely on either further characterization of the additional cell types present in cultures (both neuronal and nonneuronal) or the development of methods to isolate cell types of interest.

iPSCs and hESCs generally differentiate into a heterogeneous mix of differentiated cell types and undifferentiated cells in vitro. But recent reports of methods to select cell types of interest could provide opportunities 
both to compare differentiation efficiencies between patients quantitatively and to answer novel questions about human neurons and glia. Pruszak et al. [46] identified cell surface molecular signatures that allow the purification of neural precursor cells (NPCs) and neurons from differentiated hESCs by fluorescence-activated cell sorting (FACS). NPCs are a more restricted type of stem cell that give rise to neurons, astrocytes and oligodendrocytes. FACS-purified neurons survived replating and successfully engrafted into rodent brains. Pruszak et al. [46] also reported that FACS-purification of neurons removed tumorigenic cells, which suggests a future avenue for the preparation of transplantation-grade cells. Yuan et al. [47] identified an alternative cell surface molecular signature that could be used to purify NPCs and neurons from differentiated hESCs and iPSCs. For the purification of neurons, the methods of both Pruszak et al. [46] and Yuan et al. [47] rely on neuronal expression of the heat-stable antigen CD24. Yuan et al. [47] found that FACS-purified neurons were electrophysiologically active after replating and could be cultured without the presence of glia or other cell types for an extended period of time.

\section{iPSC-derived models of neurodegenerative diseases \\ Modeling AD}

The study of live human neurons in the absence of glia provides an opportunity to ask novel questions about AD and neurobiology in general. For example, it is unclear if many of the pathologies and biochemical alterations associated with AD occur in a cell autonomous rather than a cell-non-autonomous fashion, but this has important implications for how the disease progresses and how potential therapies should be directed. In the case of $A \beta$ toxicity, it is commonly thought that neurons secrete high levels of $A \beta$, and that some of this $A \beta$ is cleared by astrocytes and microglia $[48,49]$. By removing glial variables, purified neuronal cultures might allow a precise comparison of the secreted $A \beta$ levels of neurons from $\mathrm{AD}$ patients with those from healthy controls. In addition, such cultures should allow studies of whether the secreted factors have a non-autonomous toxic effect.

Yuan et al. [47] also identified a molecular signature for the purification of astrocytes from differentiated NPCs. The use of purified glia might make it possible to investigate the converse question: do glia from fAD and sAD patients have reduced ability to clear secreted $A \beta$ when compared with controls? A similar experimental approach has led to interesting observations about non-cellautonomous mechanisms of amyotrophic lateral sclerosis (ALS) [50-52]. Using motor neuron differentiated from embryonic stem cells (from either mice or humans), two research groups [50-52] have found that primary glial cells harboring mutations found in ALS are selectively toxic to these neurons.

Despite rapid progress in neuronal differentiation methods, several issues regarding the utility of iPSCderived neurons remain unresolved. One major issue is variability in differentiation propensity between cell lines. Marked differences in differentiation propensity between pluripotent stem cell lines, even between iPSC lines generated from the same individual, have been reported $[53,54]$. As a large number of research groups have begun to compare the differentiated progeny of multiple iPSC lines, differentiation variability has become an issue of paramount importance. This issue becomes more complex if iPSC technology is to be used to investigate a disease with unknown or unclear developmental alterations. For example, altered neurogenesis has been observed in the brains of $\mathrm{AD}$ patients and $\mathrm{AD}$ animal models [55-58]. Thus, it is unclear if iPSCs and iPSCderived NPCs from AD patients should generate neurons differently than control cells. Improved methods of quantitatively monitoring differentiation will be important contributions to the stem-cell field. Differentiation methods such as those described in Pruszak et al. [46] and Yuan et al. [47] offer an approach to simultaneously quantify and purify cell types of interest.

\section{Modeling other neurodegenerative diseases in a dish}

Although human iPSCs were first reported less than 4 years ago, a handful of research groups have already reported the successful use of iPSCs in neurologic disease modeling. In 2009, Ebert et al. [59] were the first to report a phenotype in vitro when they demonstrated the partial modeling of spinal muscular atrophy (SMA) type I. Earlier this year, Nguyen et al. [60] reported the successful partial modeling of Parkinson's disease (PD), a neurodegenerative disease that has some similar pathologies to AD.

SMA type I is a childhood neurodegenerative disease characterized by selective loss of $\alpha$-motor neurons. This autosomal recessive disease is caused by mutations in Survival motor neuron 1 (SMN) that reduce SMN protein levels [61,62]. Ebert et al. [59] generated iPSCs from one SMA patient and his unaffected mother. One patient and one control iPSC line were then differentiated to form cultures containing motor neurons, which were assessed by the expression of proteins such as ChAT and the transcription factor HB9. The differentiated cultures from the patient iPSC line had reduced expression levels of SMN and reduced numbers of SMN nuclear aggregates termed 'gems', consistent with disease pathogenesis. Interestingly, the neuronal cultures from the patient differentiated for just 6 weeks had significantly reduced numbers of $\mathrm{ChAT}^{+}$neurons when compared with the control samples. 
To explore the potential of iPSC technology as a platform for drug validation, the differentiated cultures were treated with valproic acid and tobramycin, two drugs previously shown to increase aberrant SMN expression [63-65]. Both drugs caused modest but significant increases in SMN protein levels, and both drugs caused partial rescue of gem levels. These findings demonstrate that iPSCs can be used to model aspects of a monogenic neurodegenerative disease and can also be used as a drug validation platform. In the future, it will be important to build upon this important proof-of-principle study by analyzing additional patients and controls, as well as additional iPSC lines from each patient. Because there is strong evidence of intrinsic non-genetic variability between iPSC lines, it will be important to determine if these findings apply to additional cell lines.

PD has received a relatively large amount of attention from the iPSC field. Multiple research groups have reported the generation of iPSCs from PD patients $[60,66,67]$, but until recently, it was unclear if differentiated PD iPSCs displayed disease phenotypes. PD is the second most common neurodegenerative disease after AD. Its pathological hallmarks include intracellular accumulations of $\alpha$-synuclein protein in the form of Lewy bodies and Lewy neurites, and selective loss of dopaminergic (DA) neurons in the substantia nigra of the midbrain $[68,69]$. The majority of PD cases, like those of $\mathrm{AD}$, are apparently sporadic, but rare familial forms of the disease exist.

The G2019S mutation of Leucine-rich repeat kinase 2 (LRRK2) is a relatively common autosomal dominant mutation that causes familial PD [70-72]. Nguyen et al. [60] recently reported interesting phenotypes in iPSCderived neuronal cultures from one patient with a G2019S mutation, which they compared with neurons from one control individual. In this study, two clonal iPSC lines from the patient were differentiated into cultures containing electrophysiologically active neurons that expressed DA proteins, such as tyrosine hydroxylase $(\mathrm{TH})$ and FOXA2. Relative to control samples, the DAexpressing cultures from the patient expressed increased levels of $\alpha$-synuclein. In addition, the $\mathrm{TH}^{+}$neurons in the patient samples were more vulnerable to cell death induced by oxidative damage when the cultures were challenged with hydrogen peroxide or 6-hydroxydopamine. The Nguyen et al. study [60] represents an important step towards an accurate human model of a monogenic adult-onset neurodegenerative disease. Although it takes decades for overt PD to manifest in patients, iPSCderived neurons differentiated for only 35 days displayed phenotypic differences. In the future, it will be important to determine if these findings can be extended to additional familial PD patients and if iPSCderived neurons from sporadic PD patients can resemble familial samples.
The reports of the partial modeling of PD and SMA with iPSCs illustrates the current state of the art of neurodegenerative disease modeling with iPSCs, and hints that this approach could be applied to AD.

\section{AD therapeutics}

Beyond the use of iPSC technology to increase our understanding of $\mathrm{AD}$, this technology also has the potential to serve as a platform for $\mathrm{AD}$ therapeutic validation and development. In other neurologic diseases, iPSCs have been used to test the mechanistic effect of drugs $[45,59,60,73]$. In AD, several drugs that were developed using animal models have not performed as expected in clinical trials, and with iPSCs, there could now be an opportunity to determine if this is explained by betweenspecies differences.

Evidence also exists that stem cells, including iPSCs, can serve as therapeutic vehicles in their own right. Blurton-Jones et al. [74] demonstrated that transplanted NPCs improved cognitive deficits in a mouse model of AD. Normally, aged mice that are transgenic for mutant APP, mutant presenilin 1 and mutant tau show impaired performance in cognitive tasks such as the Morris water maze and context-dependent novel object recognition. The reduced performance in both of these paradigms was, however, significantly rescued when neural stem cells (NSCs) were transplanted into hippocampi. Interestingly, these transplants also caused significant increases in synaptic density in the hippocampus, one of the best correlates of cognitive function in $\mathrm{AD}$ patients [75]. Blurton-Jones et al. [74] provided evidence that the improvements in cognition and synaptic density were due to the secretion of brain-derived neurotrophic factor (BDNF) by the engrafted cells. Although the transplants did not appear to ameliorate the root causes of the deficits (the $A \beta$ and tau pathologies were unchanged), this study provides initial evidence that stem cells might serve as therapeutic vehicles in the treatment of AD.

In the future, iPSCs that are differentiated into NSCs or neurons may also serve as a source of transplantable material. In a rodent model of PD, both mouse iPSCs that were differentiated into NSCs and human iPSCs differentiated into neurons were successfully engrafted into brains and ameliorated motor symptoms [76,77]. However, the previously discussed genetic aberrations observed in iPSCs, even if present in small in quantity, are a major issue that needs to be addressed before transplantationgrade preparations can be made. Extensive genetic screening prior to clinical use might be required as standard procedure.

\section{Conclusions and future directions}

Factors such as the limited availability of live patient samples, the failure of mouse models of fAD to 
recapitulate $\mathrm{AD}$ pathogenesis fully and the inability to study SAD in animal models suggest that live patientspecific cellular models would be especially beneficial to $\mathrm{AD}$ research, as long as they can accurately recapitulate important aspects of the pathogenesis. Such models, including iPSCs, have the potential to serve as novel, powerful tools that could help elucidate which pathologies are the primary initiators and accelerators of $\mathrm{AD}$ pathogenesis, and could also serve as platforms for therapeutic development.

Recent GWASs have identified multiple susceptibility genes in SAD, including APOE, CLU, CR1 and PICALM. It has been proposed that the risk variants of these genes contribute to $A D$ pathogenesis by altering $A \beta$ concentrations, but their true role in $\mathrm{AD}$ remains unclear, as do most of the precise risk-modifying genetic changes that occur in these genes. Creating iPSC models of sAD patients with high expressivity of risk variants might allow validation and further elucidation of GWAS findings.

The successful use of iPSC technology in the partial modeling of other neurologic diseases, coupled with recent advances in neuronal differentiation and the high degree of iPSC genetic fidelity, provides evidence that iPSCs have the potential to provide novel insight into AD mechanisms and therapies. Many neuronal subtypes are lost by the end-stages of $\mathrm{AD}$, but forebrain cholinergic neurons and glutamatergic neurons are commonly thought to be preferentially affected in the early stages. Recently published differentiation protocols demonstrate that it is possible to generate these subtypes of neurons from pluripotent stem cells, although unknown and/or unwanted cell types may also be generated in the same cultures. Other recent protocols that provide methods to purify NPCs, neurons and glia from differentiated cultures are likely to be very useful when comparing the differentiation efficiencies of different iPSC lines, when seeking to remove tumorigenic cells from cultures destined for transplantation, and in the isolation of specific cell types of interest.

Within the past few years, iPSCs have been used to create in vitro models of other neurologic diseases, including PD, which often shares overlapping pathologies with $\mathrm{AD}$. Investigations into these diseases have shown that iPSC models are especially suited to the study of live cell and early aspects of disease pathogenesis. For AD, there are many attractive targets for this type of analysis, including the toxicity, clearance and localization of $A \beta$ and other derivatives of APP processing. iPSC technology might also be useful in determining which processes aggravate or prevent tau phosphorylation and aggregation, an area of investigation that is problematic at present because of differences in the tau protein between rodents and humans.
Although the initial successes with disease modeling using iPSCs have generated great excitement, and justly so, they are only the first step in what will continue to be a difficult experimental process of elucidating the root causes of chronic and common diseases such as AD. We anticipate that significant progress on $\mathrm{AD}$ involving these methods will require particularly rigorous and quantitative applications of this promising technology. For example, to minimize

the introduction of artifacts during the iPSC-derivation process, future studies should ideally reprogram primary cells with similar culture histories, and all patients and controls should be represented by more than one, probably as many as three or more, independently derived iPSC lines. Similarly, for the validation of newly generated iPSC lines, genomic fidelity should be estimated, minimally at G-banding resolution, and it should be demonstrated that there is no major difference in iPSC quality between individuals (for example, by quantitative analysis of transgene silencing and pluripotency marker expression). Proof of pluripotency by teratoma formation, in its current form, probably need not remain a required assay for disease modeling studies that use pre-established derivation methods, as much more quantitative methods exist to assay iPSC quality and differentiation.

Additional requirements for elucidating $\mathrm{AD}$ mechanisms might require better control of differentiation itself. Because variability in differentiation propensity can exist between stem cell lines, it is very difficult to draw strong conclusions from a disease modeling study that does not quantitatively characterize the differentiation process and the resultant cultures. For neuronal cultures, informative measurements include the proportion of neurons in culture, the subtypes of neurons present, and the degree of neuronal maturity, which can be estimated using electrophysiological methods. Some studies might require pure neurons, whereas experiments on mixtures of neurons and glia will require the ability to purify both cell types and to recombine them in culture in defined proportions over extended culture times. Finally, the ability for readers to interpret results will also be greatly improved if publications report more clearly the number of patients, iPSC lines and biological replicates analyzed in each dataset.

Specific to the study of AD, it will be important in the near future to provide proof-of-principle studies that determine whether iPSCs are capable of recapitulating aspects of $\mathrm{AD}$ pathogenesis and whether they can be used to validate and further elucidate findings from $A D$ GWAS. As AD takes decades to manifest in patients, it might be challenging to create informative in vitro models of $\mathrm{AD}$ on a reasonable time frame. Furthermore, it is unclear if iPSCs can be used to model sporadic forms of the disease, which are thought to involve 
environmental factors and/or somatic mutations. For a sufficiently powered investigation into the heterogeneity of sAD, large numbers of patients and control individuals will need to be examined. Thus, an important future benchmark will be improved methods to generate large numbers of iPSC lines.

Despite these challenges, iPSCs have the potential to provide great insight into the mechanisms that initiate and accelerate the onset of AD. This new insight could lead to improved prospective diagnostics and better targets for therapeutic development for one of the world's most important diseases.

\section{Abbreviations}

$A \beta$, amyloid $\beta ; A D$, Alzheimer's disease; ALS, amyotrophic lateral sclerosis; APOE4, Apolipoprotein E 4; APP, amyloid precursor protein; ChAT, choline acetyltransferase; CLU, Clusterin gene; CNV, copy number variant; CR1, Complement receptor type 1 gene; DA, dopaminergic; FACS, fluorescenceactivated cell sorting; fAD, familial AD; GWAS, genome-wide association study; hESC, human embryonic stem cell; iPSC, induced pluripotent stem cell; NPC, neural precursor cell; NSC, neural stem cell; PD, Parkinson's disease; PICALM, phosphatidylinositol-binding clathrin assembly protein gene; SAD, sporadic form of AD; SMA, spinal muscular atrophy; SMN, Survival motor neuron 1 gene; SNP, single nucleotide polymorphism; TH, tyrosine hydroxylase.

Published: 27 July 2011

\section{References}

1. Querfurth HW, LaFerla FM: Alzheimer's disease. N Engl J Med 2010, 362:329-344.

2. Citron M: Alzheimer's disease: strategies for disease modification. Nat Rev Drug Discov 2010, 9:387-398.

3. Alzheimer A: About a peculiar disease of the cortex (in German). Allg Z Psychiat Med 1907, 64:146-148.

4. Tanzi RE, Bertram L: Twenty years of the Alzheimer s disease amyloid hypothesis: a genetic perspective. Cell 2005, 120:545-555.

5. Cataldo AM, Peterhoff CM, Troncoso JC, Gomez-Isla T, Hyman BT, Nixon RA: Endocytic pathway abnormalities precede amyloid beta deposition in sporadic Alzheimer's disease and Down syndrome: differential effects of APOE genotype and presenilin mutations. Am J Patho/ 2000, 157:277-286.

6. Stokin GB, Lillo C, Falzone TL, Brusch RG, Rockenstein E, Mount SL, Raman R, Davies P, Masliah E, Williams DS, Goldstein LSB: Axonopathy and transport deficits early in the pathogenesis of Alzheimer's disease. Science 2005, 307:1282-1288

7. Goate A, Chartier-Harlin M-C, Mullan M, Brown J, Crawford F, Fidani L, Giuffra L, Haynes A, Irving N, James L, Mant R, Newton P, Rooke K, Roques P, Talbot C, Pericak-Vance M, Roses A, Williamson R, Rossor M, Owen M, Hardy J: Segregation of a missense mutation in the amyloid precursor protein gene with familial Alzheimer's disease. Nature 1991, 349:704-706

8. Levy-Lahad E, Wasco W, Poorkaj P, Romano D, Oshima J, Pettingell W, Yu C, Jondro P, Schmidt S, Wang K, Crowley AC, Fu Y-H, Guenette SY, Galas D, Nemens E, Wijsman EM, Bird TD, Schellenberg GD, Tanzi RE: Candidate gene for the chromosome 1 familial Alzheimer's disease locus. Science 1995, 269:973-977.

9. Rogaev El, Sherrington R, Rogaeva EA, Levesque G, Ikeda M, Liang Y, Chi H, Lin C, Holman K, Tsuda T, Mar L, Sorbi S, Nacmias B, Piacentini S, Amaducci L, Chumakov I, Cohen D, Lannfelt L, Fraser PE, Rommens JM, George-Hyslop PHS: Familial Alzheimer's disease in kindreds with missense mutations in a gene on chromosome 1 related to the Alzheimer's disease type 3 gene. Nature 1995, 376:775-778.

10. Sherrington R, Rogaev El, Liang Y, Rogaeva EA, Levesque G, Ikeda M, Chi H, Lin C, Li G, Holman K, Tsuda T, Mar L, Foncin JF, Bruni AC, Montesi MP, Sorbi S, Rainero I, Pinessi L, Nee L, Chumakov I, Pollen D, Brookes A, Sanseau P, Polinsky RJ, Wasco W, Da Silva HAR, Haines JL, Pericak-Vance MA, Tanzi RE, Roses $A D$, et al:: Cloning of a gene bearing missense mutations in earlyonset familial Alzheimer's disease. Nature 1995, 375:754-760.

11. De Strooper B, Saftig P, Craessaerts K, Vanderstichele H, Guhde G, Annaert W Von Figura K, Van Leuven F: Deficiency of presenilin-1 inhibits the normal cleavage of amyloid precursor protein. Nature 1998, 391:387-390.
12. Hardy J, Selkoe DJ: The amyloid hypothesis of Alzheimer's disease: progress and problems on the road to therapeutics. Science 2002, 297:353-356.

13. Pimplikar SW, Nixon RA, Robakis NK, Shen J, Tsai L-H: Amyloid-independent mechanisms in Alzheimer's disease pathogenesis. J Neurosci 2010, 30:14946-14954

14. Wong PC, Cai H, Borchelt DR, Price DL: Genetically engineered mouse models of neurodegenerative diseases. Nat Neurosci 2002, 5:633-639.

15. Oddo S, Caccamo A, Shepherd JD, Murphy MP, Golde TE, Kayed R, Metherate R, Mattson MP, Akbari Y, LaFerla FM: Triple-transgenic model of Alzheimer's disease with plaques and tangles: intracellular $A \beta$ and synaptic dysfunction. Neuron 2003, 39:409-421.

16. Guela C, Wu C-K, Saroff D, Lorenzo A, Yuan M, Yankner BA: Aging renders the brain vulnerable to amyloid $\beta$-protein neurotoxicity. Nat Med 1998, 4:827-831.

17. Campion D, Dumanchin C, Hannequin D, Dubois B, Belliard S, Puel M, Thomas-Anterion C, Michon A, Martin C, Charbonnier F, Raux G, Camuzat A, Penet C, Mesnage V, Martinez M, Clerget-Darpoux F, Brice A, Frebourg T: Early-onset autosomal dominant Alzheimer disease: prevalence, genetic heterogeneity, and mutation spectrum. Am J Hum Genet 1999, 65:664-670.

18. Gatz M, Reynolds CA, Fratiglioni L, Johansson B, Mortimer JA, Berg S, Fiske A Pedersen NL: Role of genes and environments for explaining Alzheimer disease. Arch Gen Psychiatry 2006, 63:168-174.

19. Bettens K, Sleegers K, Van Broeckhoven C: Current status on Alzheimer disease molecular genetics: from past, to present, to future. Hum Mol Genet 2010, 19:R4-R11.

20. Reitz C, Cheng R, Rogaeva E, Lee JH, Tokuhiro S, Zou F, Bettens K, Sleegers K, Tan EK, Kimura R, Shibata N, Arai H, Kamboh MI, Prince JA, Maier W, Riemenschneider M, Owen M, Harold D, Hollingworth P, Cellini E, Sorbi S, Nacmias B, Takeda M, Pericak-Vance MA, Haines JL, Younkin S, Williams J, van Broeckhoven C, Farrer LA, St George-Hyslop PH, et al: Meta-analysis of the association between variants in SORL1 and Alzheimer disease. Arch Neurol 2011, 68:99-106

21. Harold D, Abraham R, Hollingworth P, Sims R, Gerrish A, Hamshere ML, Pahwa JS, Moskvina V, Dowzell K, Williams A, Jones N, Thomas C, Stretton A, Morgan AR, Lovestone S, Powell J, Proitsi P, Lupton MK, Brayne C, Rubinsztein DC, Gill M, Lawlor B, Lynch A, Morgan K, Brown KS, Passmore PA, Craig D, McGuinness B, Todd S, Holmes C, et al.: Genome-wide association study identifies variants at CLU and PICALM associated with Alzheimer's disease. Nat Genet 2009, 41:1088-1093.

22. Lambert J-C, Heath S, Even G, Campion D, Sleegers K, Hiltunen M, Combarros O, Zelenika D, Bullido MJ, Tavernier B, Letenneur L, Bettens K, Berr C, Pasquier F, Fievet N, Barberger-Gateau P, Engelborghs S, De Deyn P, Mateo I, Franck A, Helisalmi S, Porcellini E, Hanon O, de Pancorbo MM, Lendon C, Dufouil C, Jaillard C, Leveillard T, Alvarez V, Bosco P, et al.: Genome-wide association study identifies variants at CLU and CR1 associated with Alzheimer's disease. Nat Genet 2009, 41:1094-1099.

23. Seshadri S, Fitzpatrick AL, Ikram MA, DeStefano AL, Gudnason V, Boada M, Bis JC, Smith AV, Carrasquillo MM, Lambert JC, Harold D, Schrijvers EMC, RamirezLorca R, Debette S, Longstreth WT, Janssens ACJW, Pankratz VS, Dartigues JF, Hollingworth P, Aspelund T, Hernandez I, Beiser A, Kuller LH, Koudstaal PJ, Dickson DW, Tzourio C, Abraham R, Antunez C, Du Y, Rotter Jl, et al:: Genomewide analysis of genetic loci associated with Alzheimer disease. JAMA 2010, 303:1832-1840.

24. Kim J, Basak JM, Holtzman DM: The role of Apolipoprotein E in Alzheimer's disease. Neuron 2009, 63:287-303.

25. Vance JE, Hayashi $\mathrm{H}$ : Formation and function of apolipoprotein Econtaining lipoproteins in the nervous system. BBA-Mol Cell Biol L 2010, 1801:806-818.

26. Sleegers K, Lambert J-C, Bertram L, Cruts M, Amouyel P, Van Broeckhoven C: The pursuit of susceptibility genes for Alzheimer's disease: progress and prospects. Trends Genet 2010, 26:84-93.

27. Bertram L, Lill CM, Tanzi RE: The genetics of Alzheimer disease: back to the future. Neuron 2010, 68:270-281

28. Rogers J, Li R, Mastroeni D, Grover A, Leonard B, Ahern G, Cao P, Kolody H, Vedders $L$, Kolb WP, Sabbagh M: Peripheral clearance of amyloid $\beta$ peptide by complement C3-dependent adherence to erythrocytes. Neurobiol Aging 2006, 27:1733-1739.

29. Harel A, Wu F, Mattson MP, Morris CM, Yao PJ: Evidence for CALM in directing VAMP2 trafficking. Traffic 2008, 9:417-429.

30. Nixon RA: Endosome function and dysfunction in Alzheimer's disease and other neurodegenerative diseases. Neurobiol Aging 2005, 26:373-382. 
31. Marchetto MCN, Winner B, Gage FH: Pluripotent stem cells in neurodegenerative and neurodevelopmental diseases. Hum Mol Genet 2010, 19:R71-R76

32. Zhu H, Lensch MW, Cahan P, Daley GQ: Investigating monogenic and complex diseases with pluripotent stem cells. Nat Rev Genet 2011, 12:266-275.

33. Gonzalez F, Boue S, Belmonte JCl: Methods for making induced pluripotent stem cells: reprogramming a la carte. Nat Rev Genet 2011, 12:231-242.

34. Pang ZP, Yang $N$, Vierbuchen $T$, Ostermeier A, Fuentes DR, Yang $T Q$, Citri A, Sebastiano V, Marro S, Sudhof TC, Wernig M: Induction of human neuronal cells by defined transcription factors. Nature 2011. in press.

35. Mayshar Y, Ben-David U, Lavon N, Biancotti J-C, Yakir B, Clark AT, Plath K, Lowry WE, Benvenisty N: Identification and classification of chromosomal aberrations in human induced pluripotent stem cells. Cell Stem Cell 2010, 7:521-531.

36. Laurent LC, Ulitsky I, Slavin I, Tran H, Schork A, Morey R, Lynch C, Harness JV, Lee S, Barrero MJ, Ku S, Martynova M, Semechkin R, Galat V, Gottesfeld J, Belmonte JCI, Murry C, Keirstead HS, Park H-S, Schmidt U, Laslett AL, Muller F-J, Nievergelt CM, Shamir R, Loring JF: Dynamic changes in the copy number of pluripotency and cell proliferation genes in human ESCs and iPSCs during reprogramming and time in culture. Cell Stem Cell 2011, 8:106-118.

37. Gore A, Li Z, Fung H-L, Young JE, Agarwal S, Antosiewicz-Bourget J, Canto I, Giorgetti A, Israel MA, Kiskinis E, Lee J-H, Loh Y-H, Manos PD, Montserrat N, Panopoulos AD, Ruiz S, Wilbert ML, Yu J, Kirkness EF, Belmonte JCI, Rossi DJ, Thomson JA, Eggan K, Daley GQ, Goldstein LSB, Zhang K: Somatic coding mutations in human induced pluripotent stem cells. Nature 2011, 471:63-67.

38. Hussein SM, Batada NN, Vuoristo S, Ching RW, Autio R, Narva E, Ng S, Sourour M, Hamalainen R, Olsson C, Lundin K, Mikkola M, Trokovic R, Peitz M, Brustle O, Bazett-Jones DP, Alitalo K, Lahesmaa R, Nagy A, Otonkoski T: Copy number variation and selection during reprogramming to pluripotency. Nature 2011, 471:58-62

39. Zwaka TP, Thomson JA: Homologous recombination in human embryonic stem cells. Nat Biotech 2003, 21:319-321.

40. Zou J, Maeder ML, Mali P, Pruett-Miller SM, Thibodeau-Beganny S, Chou B-K, Chen G, Ye Z, Park I-H, Daley GQ, Porteus MH, Joung JK, Cheng L: Gene targeting of a disease-related gene in human induced pluripotent stem and embryonic stem cells. Cell Stem Cell 2009, 5:97-110.

41. Hockemeyer D, Soldner F, Beard C, Gao Q, Mitalipova M, DeKelver RC, Katibah GE, Amora R, Boydston EA, Zeitler B, Meng X, Miller JC, Zhang L, Rebar EJ, Gregory PD, Urnov FD, Jaenisch R: Efficient targeting of expressed and silent genes in human ESCs and iPSCs using zinc-finger nucleases. Nat Biotech 2009, 27:851-857.

42. Selkoe DJ: Alzheimer's disease is a synaptic failure. Science 2002, 298:789-791.

43. Nilbratt M, Porras O, Marutle A, Hovatta O, Nordberg A: Neurotrophic factors promote cholinergic differentiation in human embryonic stem cellderived neurons. J Cell Mol Med 2010, 14:1476-1484.

44. Bissonnette CJ, Lyass L, Bhattacharyya BJ, Belmadani A, Miller RJ, Kessler JA: The controlled generation of functional basal forebrain cholinergic neurons from human embryonic stem cells. Stem Cells 2011, 29:802-811.

45. Marchetto MCN, Carromeu C, Acab A, Yu D, Yeo GW, Mu Y, Chen G, Gage FH, Muotri AR: A model for neural development and treatment of Rett syndrome using human induced pluripotent stem cells. Cell 2010, 143:527-539.

46. Pruszak J, Ludwig W, Blak A, Alavian K, Isacson O: CD15, CD24, and CD29 define a surface biomarker code for neural lineage differentiation of stem cells. Stem Cells 2009, 27:2928-2940.

47. Yuan SH, Martin J, Elia J, Flippin J, Paramban RI, Hefferan MP, Vidal JG, Mu Y, Killian RL, Israel MA, Emre N, Marsala S, Marsala M, Gage FH, Goldstein LS, Carson CT: Cell-surface marker signatures for the isolation of neural stem cells, glia and neurons derived from human pluripotent stem cells. PLOS One 2011, 6:e17540.

48. Funato H, Yoshimura M, Yamazaki T, Saido TC, Ito Y, Yokofujita J, Okeda R, Ihara $Y$ : Astrocytes containing amyloid beta-protein $(A \beta)$-positive granules are associated with $A \beta 40$-positive diffuse plaques in the aged human brain. Am J Pathol 1998, 152:983-992.

49. Mitrasinovic OM, Murphy GM: Accelerated phagocytosis of amyloid- $\beta$ by mouse and human microglia overexpressing the macrophage colonystimulating factor receptor. J Biol Chem 2002, 277:29889-29896.
50. Di Giorgio FP, Carrasco MA, Siao MC, Maniatis T, Eggan K: Non-cell autonomous effect of glia on motor neurons in an embryonic stem cellbased ALS model. Nat Neurosci 2007, 10:608-614

51. Marchetto MCN, Muotri AR, MuY, Smith AM, Cezar GG, Gage FH: Non-cellautonomous effect of human SOD1G37R astrocytes on motor neurons derived from human embryonic stem cells. Cell Stem Cell 2008, 3:649-657.

52. Di Giorgio FP, Boulting GL, Bobrowicz S, Eggan KC: Human embryonic stem cell-derived motor neurons are sensitive to the toxic effect of glial cells carrying an ALS-causing mutation. Cell Stem Cell 2008, 3:637-648.

53. Osafune K, Caron L, Borowiak M, Martinez RJ, Fitz-Gerald CS, Sato Y, Cowan CA, Chien KR, Melton DA: Marked differences in differentiation propensity among human embryonic stem cell lines. Nat Biotechno/ 2008, 26:313-315.

54. Bock C, Kiskinis E, Verstappen G, Gu H, Boulting G, Smith ZD, Ziller M, Croft GF, Amoroso MW, Oakley DH, Gnirke A, Eggan K, Meissner A: Reference maps of human ES and iPS cell variation enable high-throughput characterization of pluripotent cell lines. Cell 2011, 144:439-452.

55. Boekhoorn K, Joels M, Lucassen PJ: Increased proliferation reflects glial and vascular-associated changes, but not neurogenesis in the presenile Alzheimer hippocampus. Neurobiol Dis 2006, 24:1-14.

56. Jin K, Peel AL, Mao XO, Xie L, Cottrell BA, Henshall DC, Greenberg DA: Increased hippocampal neurogenesis in Alzheimer's disease. Proc Natl Acad Sci USA 2004, 101:343-347.

57. Jin K, Galvan V, Xie L, Mao XO, Gorostiza OF, Bredesen DE, Greenberg DA Enhanced neurogenesis in Alzheimer's disease transgenic (PDGFAPPSw,Ind) mice. Proc Natl Acad Sci USA 2004, 101:13363-13367.

58. Haughey N, Liu D, Nath A, Borchard A, Mattson M: Disruption of neurogenesis in the subventricular zone of adult mice, and in human cortical neuronal precursor cells in culture, by amyloid $\beta$-peptide. NeuroMol Med 2002, 1:125-135.

59. Ebert AD, Yu J, Rose FF, Mattis VB, Lorson CL, Thomson JA, Svendsen CN: Induced pluripotent stem cells from a spinal muscular atrophy patient. Nature 2009, 457:277-280

60. Nguyen HN, Byers B, Cord B, Shcheglovitov A, Byrne J, Gujar P, Kee K, Schüle B, Dolmetsch RE, Langston W, Palmer TD, Pera RR: LRRK2 mutant iPSC-derived DA neurons demonstrate increased susceptibility to oxidative stress. Cell Stem Cell 2011, 8:267-280.

61. Lefebvre $S$, Bürglen $L$, Reboullet $S$, Clermont $O$, Burlet P, Viollet $L$, Benichou B, Cruaud C, Millasseau P, Zeviani M, Le Paslier D, Frézal J, Cohen D, Weissenbach J, Munnich A, Melki J: Identification and characterization of a spinal muscular atrophy-determining gene. Cell 1995, 80:155-165.

62. Coovert DD, Le TT, McAndrew PE, Strasswimmer J, Crawford TO, Mendell JR, Coulson SE, Androphy EJ, Prior TW, Burghes AHM: The survival motor neuron protein in spinal muscular atrophy. Hum Mol Genet 1997, 6:1205-1214.

63. Brichta L, Hofmann Y, Hahnen E, Siebzehnrubl FA, Raschke H, Blumcke I, Eyupoglu IY, Wirth B: Valproic acid increases the SMN2 protein level: a wellknown drug as a potential therapy for spinal muscular atrophy. Hum Mol Genet 2003, 12:2481-2489.

64. Sumner CJ, Huynh TN, Markowitz JA, Perhac JS, Hill B, Coovert DD, Schussler K, Chen X, Jarecki J, Burghes AHM, Taylor JP, Fischbeck KH: Valproic acid increases SMN levels in spinal muscular atrophy patient cells. Ann Neurol 2003, 54:647-654.

65. Wolstencroft EC, Mattis V, Bajer AA, Young PJ, Lorson CL: A non-sequencespecific requirement for SMN protein activity: the role of aminoglycosides in inducing elevated SMN protein levels. Hum Mol Genet 2005, 14:1199-1210

66. Park I-H, Arora N, Huo H, Maherali N, Ahfeldt T, Shimamura A, Lensch MW, Cowan C, Hochedlinger K, Daley GQ: Disease-specific induced pluripotent stem cells. Cell 2008, 134:877-886.

67. Soldner F, Hockemeyer D, Beard C, Gao Q, Bell GW, Cook EG, Hargus G, Blak A Cooper O, Mitalipova M, Isacson O, Jaenisch R: Parkinson's disease patientderived induced pluripotent stem cells free of viral reprogramming factors. Cell 2009, 136:964-977.

68. Braak H, Sastre M, Del Tredici K: Development of a-synuclein immunoreactive astrocytes in the forebrain parallels stages of intraneuronal pathology in sporadic Parkinson's disease. Acta Neuropathol 2007, 114:231-241.

69. Goedert M: Alpha-synuclein and neurodegenerative diseases. Nat Rev Neurosci2001, 2:492-501.

70. Hernandez D, Paisan Ruiz C, Crawley A, Malkani R, Werner J, Gwinn-Hardy K, Dickson D, Wavrant DeVrieze F, Hardy J, Singleton A: The dardarin G2019S 
mutation is a common cause of Parkinson's disease but not other neurodegenerative diseases. Neurosci Lett 2005, 389:137-139.

71. Nichols WC, Pankratz N, Hernandez D, Paisán-Ruíz C, Jain S, Halter CA, Michaels VE, Reed T, Rudolph A, Shults CW, Singleton A, Foroud T: Genetic screening for a single common LRRK2 mutation in familial Parkinson's disease. Lancet 2005, 365:410-412.

72. Paisán-Ruiz C, Lang AE, Kawarai T, Sato C, Salehi-Rad S, Fisman GK, Al-Khairallah T, St George-Hyslop P, Singleton A, Rogaeva E: LRRK2 gene in Parkinson disease. Neurology 2005, 65:696-700.

73. Lee G, Papapetrou EP, Kim H, Chambers SM, Tomishima MJ, Fasano CA, Ganat YM, Menon J, Shimizu F, Viale A, Tabar V, Sadelain M, Studer L: Modelling pathogenesis and treatment of familial dysautonomia using patientspecific iPSCs. Nature 2009, 461:402-406.

74. Blurton-Jones M, Kitazawa M, Martinez-Coria H, Castello NA, Müller F-J, Loring JF, Yamasaki TR, Poon WW, Green KN, LaFerla FM: Neural stem cells improve cognition via BDNF in a transgenic model of Alzheimer disease. Proc Natl Acad Sci USA 2009, 106:13594-13599.

75. Terry RD, Masliah E, Salmon DP, Butters N, DeTeresa R, Hill R, Hansen LA, Katzman R: Physical basis of cognitive alterations in Alzheimer's disease: synapse loss is the major correlate of cognitive impairment. Ann Neurol 1991, 30:572-580.

76. Wernig M, Zhao J-P, Pruszak J, Hedlund E, Fu D, Soldner F, Broccoli V, Constantine-Paton M, Isacson O, Jaenisch R: Neurons derived from reprogrammed fibroblasts functionally integrate into the fetal brain and improve symptoms of rats with Parkinson's disease. Proc Natl Acad Sci USA 2008, 105:5856-5861.

77. Hargus G, Cooper O, Deleidi M, Levy A, Lee K, Marlow E, Yow A, Soldner F, Hockemeyer D, Hallett PJ, Osborn T, Jaenisch R, Isacson O: Differentiated Parkinson patient-derived induced pluripotent stem cells grow in the adult rodent brain and reduce motor asymmetry in Parkinsonian rats. Proc Natl Acad Sci USA 2010, 107:15921-15926.

78. Bertram L, McQueen MB, Mullin K, Blacker D, Tanzi RE: Systematic metaanalyses of Alzheimer disease genetic association studies: the AlzGene database. Nat Genet 2007, 39:17-23.

79. Goate A, Chartier-Harlin M-C, Mullan M, Brown J, Crawford F, Fidani L, Giuffra L, Haynes A, Irving N, James L, Mant R, Newton P, Rooke K, Roques P, Talbot C, Pericak-Vance M, Roses A, Williamson R, Rossor M, Owen M, Hardy J: Segregation of a missense mutation in the amyloid precursor protein gene with familial Alzheimer's disease. Nature 1991, 349:704-706.

80. Rovelet-Lecrux A, Hannequin D, Raux G, Le Meur N, Laquerriere A, Vital A, Dumanchin C, Feuillette S, Brice A, Vercelletto M, Dubas F, Frebourg T, Campion D: APP locus duplication causes autosomal dominant earlyonset Alzheimer disease with cerebral amyloid angiopathy. Nat Genet
2006, 38:24-26.

81. Saunders AM, Strittmatter WJ, Schmechel D, George-Hyslop PH, PericakVance MA, Joo SH, Rosi BL, Gusella JF, Crapper-MacLachlan DR, Alberts MJ, Hulette C, Crain B, Goldgaber D, Roses AD: Association of apolipoprotein E allele epsilon 4 with late-onset familial and sporadic Alzheimer's disease. Neurology 1993, 43:1467-1472.

82. Corder EH, Saunders AM, Strittmatter WJ, Schmechel DE, Gaskell PC, Small GW, Roses AD, Haines JL, Pericak-Vance MA: Gene dose of apolipoprotein E type 4 allele and the risk of Alzheimer's disease in late onset families. Science 1993, 261:921-923.

83. Coon KD, Myers AJ, Craig DW, Webster JA, Pearson JV, Lince DH, Zismann VL, Beach TG, Leung D, Bryden L, Halperin RF, Marlowe L, Kaleem M, Walker DG, Ravid R, Heward CB, Rogers J, Papassotiropoulos A, Reiman EM, Hardy J, Stephan DA: A high-density whole-genome association study reveals that APOE is the major susceptibility gene for sporadic late-onset Alzheimer's disease. J Clin Psychiatry 2007, 68:613-618.

84. Tycko B, Feng L, Nguyen L, Francis A, Hays A, Chung W-Y, Tang M-X, Stern Y, Sahota A, Hendrie H, Mayeux R: Polymorphisms in the human apolipoprotein-J/clusterin gene: ethnic variation and distribution in Alzheimer's disease. Hum Genet 1996, 98:430-436.

85. Rogaeva E, Meng Y, Lee JH, Gu Y, Kawarai T, Zou F, Katayama T, Baldwin CT, Cheng R, Hasegawa H, Chen F, Shibata N, Lunetta KL, Pardossi-Piquard R, Bohm C, Wakutani Y, Cupples LA, Cuenco KT, Green RC, Pinessi L, Rainero I, Sorbi S, Bruni A, Duara R, Friedland RP, Inzelberg R, Hampe W, Bujo H, Song $Y-Q$, Andersen OM, et al:: The neuronal sortilin-related receptor SORL1 is genetically associated with Alzheimer disease. Nat Genet 2007, 39:168-177.

86. Grupe A, Abraham R, Li Y, Rowland C, Hollingworth P, Morgan A, Jehu L, Segurado R, Stone D, Schadt E, Karnoub M, Nowotny P, Tacey K, Catanese J, Sninsky J, Brayne C, Rubinsztein D, Gill M, Lawlor B, Lovestone S, Holmans P, O'Donovan M, Morris JC, Thal L, Goate A, Owen MJ, Williams J: Evidence for novel susceptibility genes for late-onset Alzheimer's disease from a genome-wide association study of putative functional variants. Hum Mol Genet 2007, 16:865-873.

87. Li K, Liu S, Yao S, Wang B, Dai D, Yao L: Interaction between interleukin-8 and methylenetetrahydrofolate reductase genes modulates Alzheimer's disease risk. Dement Geriatr Cogn Disord 2009, 27:286-291.

doi:10.1186/gm265

Cite this article as: Israel MA, Goldstein LSB: Capturing Alzheimer's disease genomes with induced pluripotent stem cells: prospects and challenges. Genome Medicine 2011, 3:49. 